\title{
Notch Effects in Uniaxial Tension Specimens
}

\author{
T. J. Delph
}

\section{OAK RIDGE NATIONAL LABORATORY} OPERATED BY UNION CARBIDE CORPORATION - FOR THE DEPARTMENT OF ENERGY 


\section{DISCLAIMER}

This report was prepared as an account of work sponsored by an agency of the United States Government. Neither the United States Government nor any agency Thereof, nor any of their employees, makes any warranty, express or implied, or assumes any legal liability or responsibility for the accuracy, completeness, or usefulness of any information, apparatus, product, or process disclosed, or represents that its use would not infringe privately owned rights. Reference herein to any specific commercial product, process, or service by trade name, trademark, manufacturer, or otherwise does not necessarily constitute or imply its endorsement, recommendation, or favoring by the United States Government or any agency thereof. The views and opinions of authors expressed herein do not necessarily state or reflect those of the United States Government or any agency thereof. 


\section{DISCLAIMER}

Portions of this document may be illegible in electronic image products. Images are produced from the best available original document. 


\section{Printed in the United States of America. Available from National Technical Information Service \\ U.S. Department of Commerce \\ 5285 Port Royal Road, Springfield, Virginia 22161 \\ Price: Printed Copy $\$ 4.50$; Microfiche $\$ 3.00$}

This report was prepared as an account of work sponsored by an agency of the United States Government. Neither the United States Government nor any agency thereof, nor any of their employees, contractors, subcontractors, or their employees, makes any warranty, express or implied, nor assumes any legal liability or responsibility for any third party's use or the results of such use of any information, apparatus, product or process disclosed in this report, nor represents that its use by such third party would not infringe privately owned rights. 
ORNL/TM-6716

Dist. Category UC-79, $-79 \mathrm{~h},-79 \mathrm{k}$

Contract No. W-7405-eng-26

Engineering Technology Division

NOTCH EFFECTS IN UNIAXIAL TENSION SPECIMENS

T. J. Delph

Date Published- March, 1979

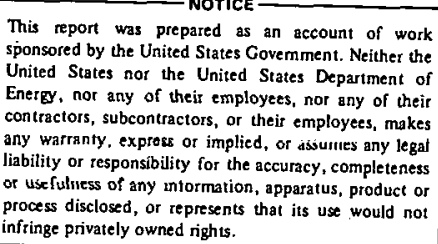

Prepared by the

OAK RIDGE NATIONAL LABORATORY

Oak Ridge, Tennessee 37830

operated by

UNION CARBIDE CORPORATION

for the

DEPARTMENT OF ENERGY 
THIS PAGE

\section{WAS INTENTIONALLY \\ LEFT BLANK}


CONTENTS

$\underline{\text { Page }}$

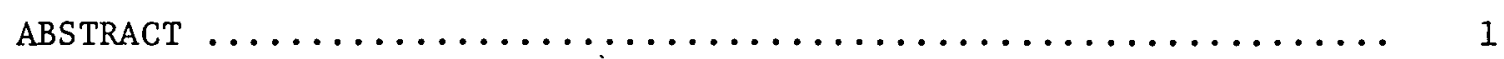

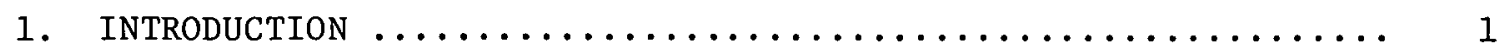

2. GENERAL FEATURES OF NOTCHED-SPECIMEN BEHAVIOR $\ldots \ldots \ldots \ldots \ldots \ldots .2$

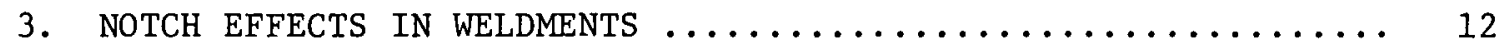

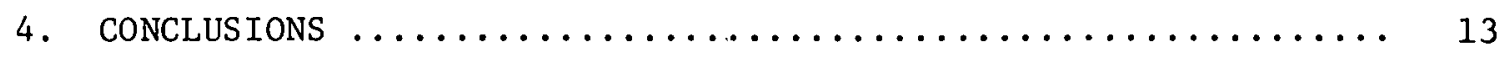

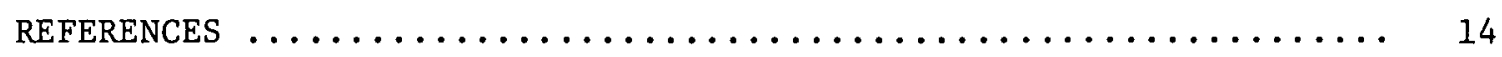

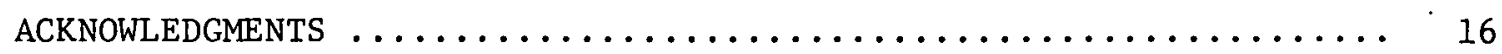


NOTCH EFFECTS IN UNIAXIAL TENSION SPECIMENS*

T. J. De1ph

ABSTRACT

This report contains the results of a literature survey on the effect of notches on the time-dependent fallure of uniaxial tension specimens at elevated temperatures. Particular attention is paid to the fallure of notched specimens containing weldments.

Keywords: failures, high-temperature plasticity, creep, time dependency, notches, weldments, creep-rupture.

\section{INTRODUCTION}

The problem of predicting the elevated-temperature failure of components with large geometrically induced stress concentrations has long been of concern to designers of gas turbines, nuclear reactor components, and other machinery intended for operation at high temperatures. One of the most widely used methods for assessing the failure sensitivity of a particular material to geometric stress concentrations is the so-called notched-bar test. Here a notch is machined into a tensile specimen that is either round or flat, and the specimen is subjected to a constant, uniaxial load until failure occurs. A comparison is then made to the failure behavior of an unnotched specimen of equal cross-sectional area, and inferences are drawn as to the sensitivity of the material to stress concentrations. Such tests were originally performed in Germany in the 1930 s in connection with failure problems in steam generating and chemical processing equipment. Presently, notched-bar tests are often required as part of the proof-testing procedure for heats of alloys intended for high-temperature applications, and guidelines for conducting such tests have heen set forth by the American Society for Testing and Materials (ASTM). ${ }^{1}$

At an early stage, workers in this area observed the apparently paradoxical result that, under certain conditions, a notched specimen of a

\footnotetext{
Work performed under DOE/RRT 189a OH048, High-Temperature Structura1 Design.
} 
given material could exhibit a larger time-to-failure than an unnotched specimen having the same nominal uniaxial stress, despite the large stress concentration known to be present in the notched specimen. The nominal uniaxial stress in the notched specimen is taken to be the spectmen load divided by the minimum specimen cross-sectional area. This phenomenon was termed notch strengthening, while the converse behavior was known as notch weakening. The reasons for notch strengthening or weakening have been the subject of much speculation by researchers (principally metallurgists), but little in the way of quantitative explanation has been offered. It is the purpose of this report to review briefly what is known in this area, particularly with regard to the effect of notches in weldments, and to give a list of references where the reader may find more details.

\section{GENERAL FEATURES OF NOTCHED-SPECIMEN BEHAVIOR}

As noted previously, the failure behavior of notched specimens has been of considerable interest, so much so that it has been the subject of several special publications, ${ }^{2,3}$ the greater part of an issue of the ASME Journal of Basic Engineering, ${ }^{4}$ and numerous papers. Most of the reported experimental results apparently were obtained with axisymmetric notched specimens of circular cross section, although a number of tests of flat specimens have also been reported. There is also some variability in the types of notch geometries considered, but the most common is a V-groove configuration with the apex of the notch rounded into a circular arc of some specified radius (Fig. 1).

Early German investigators in the field felt that notch strengthening or weakening could be correlated with smooth-bar (unnotched) ductility ${ }^{5}$ so that notch weakening might be expected to occur when the smooth-bar ductility of a material fell below a certain value; thus, notch strengthening would occur when the ductility exceeded this value. This point of view was also initially adopted by U.S. research workers. Later investigations, however, have cast increasing doubt on this conclusion, resulting in the present accepted theory that no simple relationship exists between smooth-bar ductility and notched-bar failure behavior. ${ }^{6}$ 


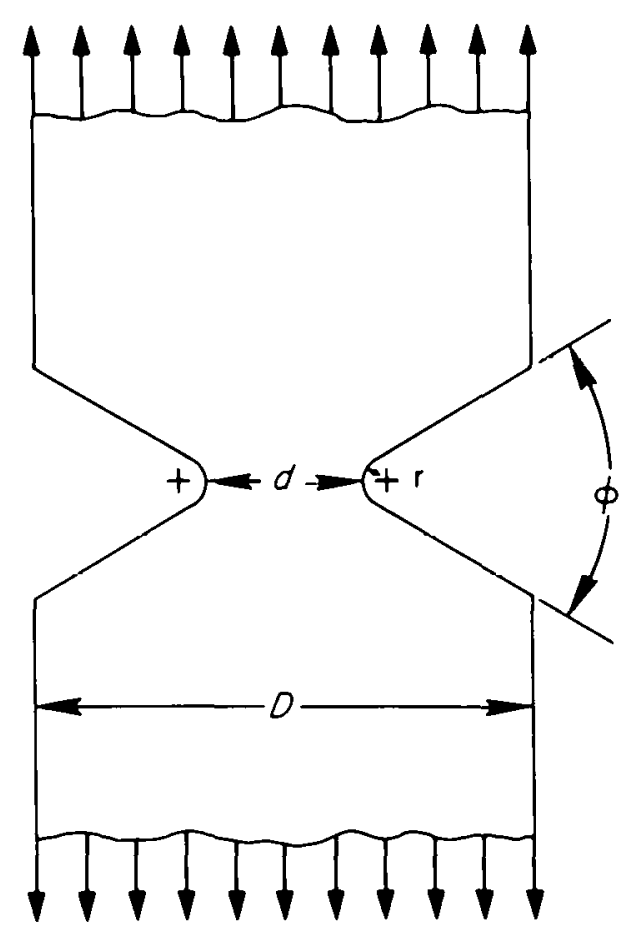

Fig. 1. V-groove notched specimen geometry.

One of the first indications that smooth-bar ductility was not a reliable index of notch sensitivity is found in the work of Davis and Manjoine. ${ }^{7}$ These authors studied the effects of varying the notch geometry on notched-bar specimens of a number of different high-temperature alloys. As expected, they discovered that the notch geometry has a profound effect on the failure behavior of the specimen. The geometrical parameters varied by the investigators were the ratio of the diameter of the notched section to the unnotched section, d/D (see Fig. 1), and the notch sharpness $\mathrm{r} / \mathrm{d}$. The notch angle $\phi$ was held constant at $60^{\circ}$. Figure 2, extracted from this study, shows the effect of varying the notch sharpness $\mathrm{r} / \mathrm{d}$ on the failure behavior of four different materials, labeled A-D. In general, as the notch becomes sharper ( $\mathrm{r} / \mathrm{d}$ decreasing), the ratio of notched-to-unnotched rupture strength increases away from unity, reaches some maximum value, and then decreases. For the sharpest notch considered $(r / d=0.01)$, alloys $A, B$, and $C$ exhibit notch-weakening 


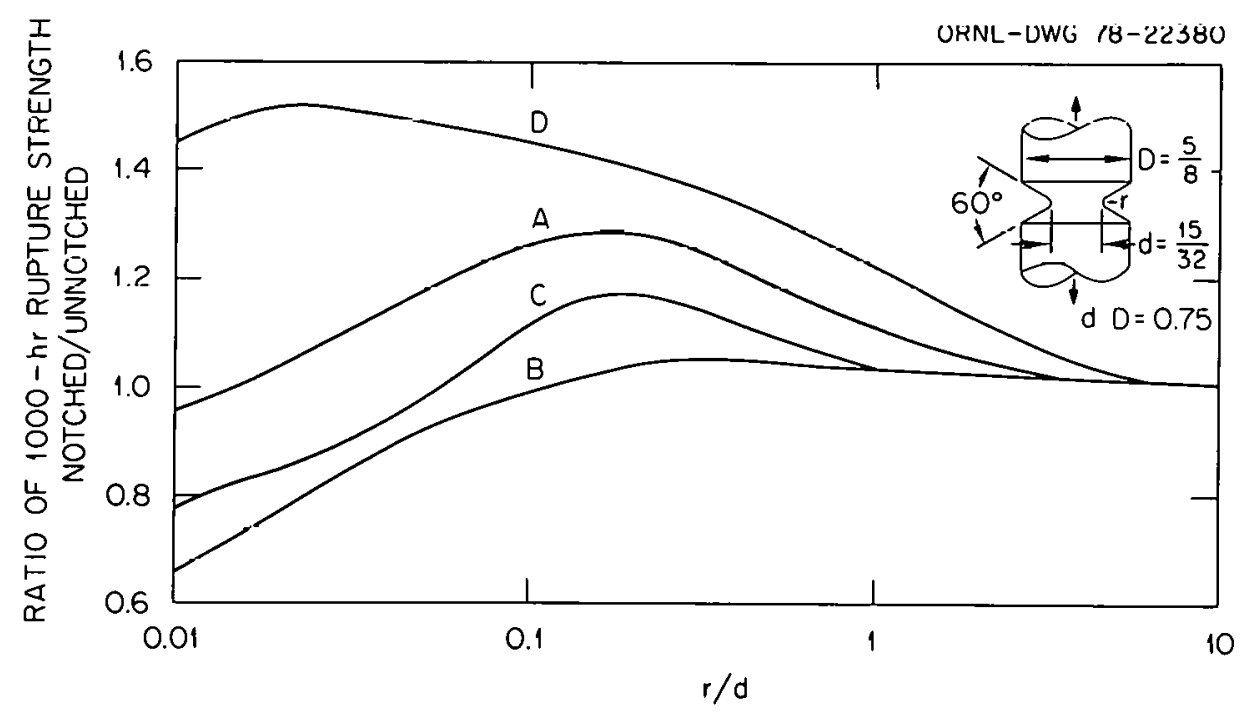

Fig. 2. Effect of notch sharpness $\mathrm{r} / \mathrm{d}$ on failure behavior of four alloys. (From Davis and Manjoine, "Effect of Notch Geometry upon Rupture Strength at Elevated Temperatures," ASTM STP No. 128. Reprinted by permission of the American Society for Testing and Materials, Copyright.)

behavior, but alloy D still shows a considerable degree of notch strengthening.

Subsequent investigations ${ }^{5,8-11}$ have demonstrated that the notch sensitivity of a particular alloy may also be affected by specimen size, prior heat treatment, loading level, and test temperature. In fact, as pointed out by Voorhees, Freeman, and Herzog, ${ }^{8}$ it appears that, depending on test conditions, any material may be made to exhibit notch-strengthening or notch-weakening behavior. Thus, it is not correct to refer to a material as being notch strengthened or weakened as though notch sensitivity was an intrinsic material property, because a material may exhibit both behaviors under ditterent conditions.

One further indication of the complexity of the notch-rupture problem is the particular $\mathrm{Z}$-shaped rupture curve reported by some investigators. ${ }^{9,12}$ Figure 3 shows a typical example. We note that two separate rupture curves apparently exist for the notched specimen, and these are connected by a transitional branch (the "leg of the $Z$ "). On this transitional branch, raising the nominal uniaxial stress can actually lead to an increase in time-to-failure. This is surprising behavior, indeed; in 


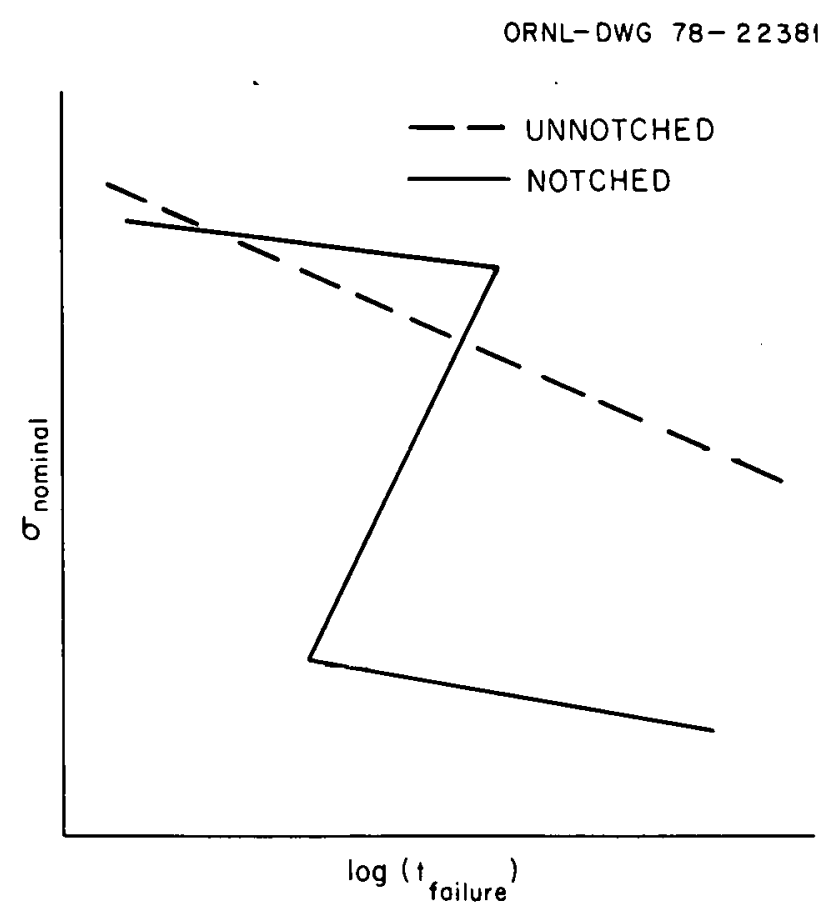

Fig. 3. Z-shaped failure curve for notched specimens.

fact, the existence of the $\mathrm{Z}$-shaped curves has been tentatively ascribed by one author ${ }^{6}$ to experimental error.

Although a good many qualitative explanations of notched-bar rupture behavior at elevated temperatures have been proposed by metallurgists, little quantitative work has been done. One exception to this statement is a paper by Taira and ohtani ${ }^{13}$ containing the results of an extensive experimental and numerical (finite-element) study of the behavior of notched specimes of $1 \mathrm{Cr}-1 \mathrm{Mo}-1 / 4 \mathrm{~V}$ steel. Specimen dimensions were $\mathrm{r}=0.075 \mathrm{~mm}$ (0.00295 in.), $\mathrm{d}=6 \mathrm{~mm}$ (0.236 in.), and $\mathrm{D}=8 \mathrm{~mm}$ (3.15 in.), with the notch angle $\phi=60^{\circ}$. Experimentally, they observed notch strengthening at higher nominal stress levels and notch weakening at lower stress levels. They then employed a finite-element analysis to predict specimen failure and were able to obtain results that agreed reasonably well with the observed failure times. The particular form of the creep damage law employed in these calculations was one in which the damage was proportional to the effective inelastic strain. 
Figures 4 and 5 show the calculated stress distributions along the minimum cross section at various times for two different values of nominal uniaxial stress. Figure 4 shows the ratio of the von Mises effective stress to the nominal uniaxial stress as a function of the distance from the notch root. Although this ratio initially has a high value at the notch root, it decreases with time to a value below unity because of relaxation and the influence of the triaxial stress field. Figure 5 shows the ratio of the axial stress component to the nominal uniaxial stress as a function of the distance from the notch root. Here we see that the axial stress component initially has its maximum value at the notch root,

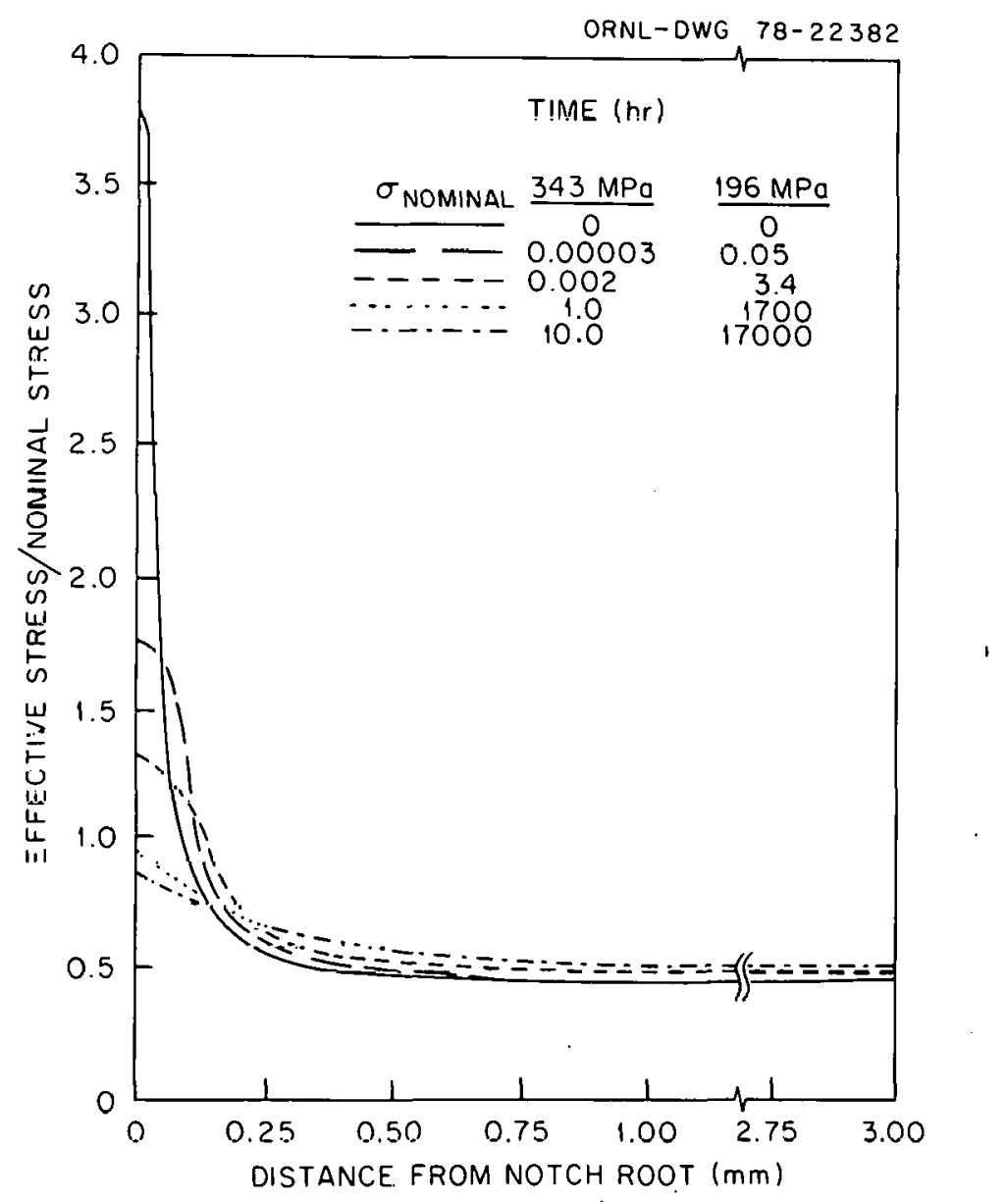

Fig. 4. Ratio of effective stress to nominal stress vs distance from notch root at minimum cross section. (1 mm $=0.0394$ in.) (From Taira and Ohtani, "Creep Crack Propagation and Creep Rupture of Notched Specimens," Creep and Fatigue in Elevated Temperature Applications, Institution of Mechanical Engineers, 1974.) 


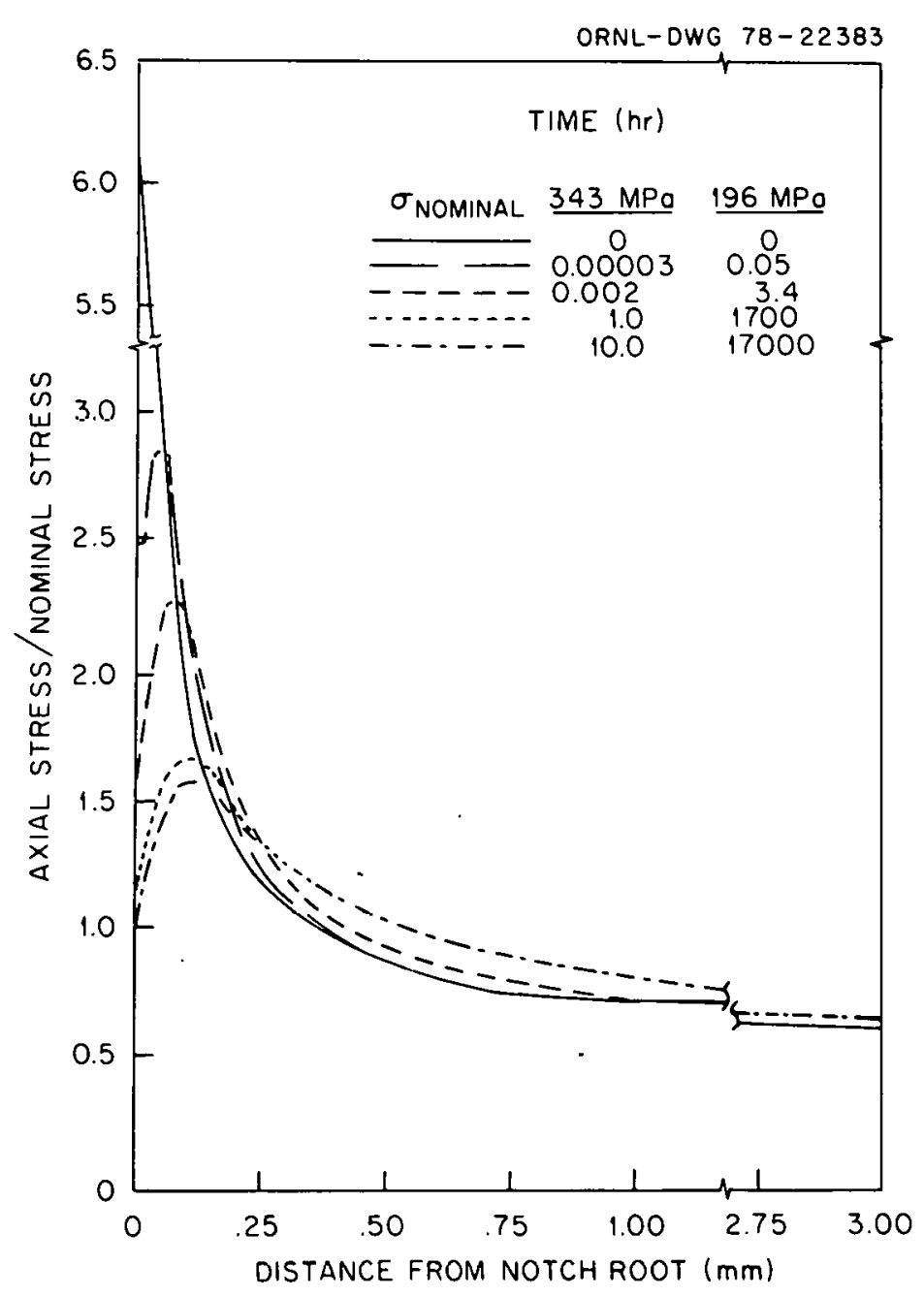

Fig. 5. Ratio of axial stress to nominal stress vs distance from notch root at minimum cross section. ( $1 \mathrm{~mm}=0.0394 \mathrm{in.)}$ (From Taira and Ohtani, "Creep Crack Propagation and Creep Rupture of Notched Specimens," Creep and Fatigue in Elevated Temperature Applications, Institution of Mechanical Enginecrs, 1974.)

but this maximum value decreases in magnitude with time and shifts in position to a location slightly interior to the notch root. Figure 6 shows the effective inelastic (creep) strain as a function of distance from the notch root along the minimum cross section. This quantity has its maximum at a point interior to the notch root, but this position seems to shift to the notch root with increasing time.

Some of the aspects of the finite-element analysis performed by Taira and Ohtani are open to serious criticism. No consideration of 


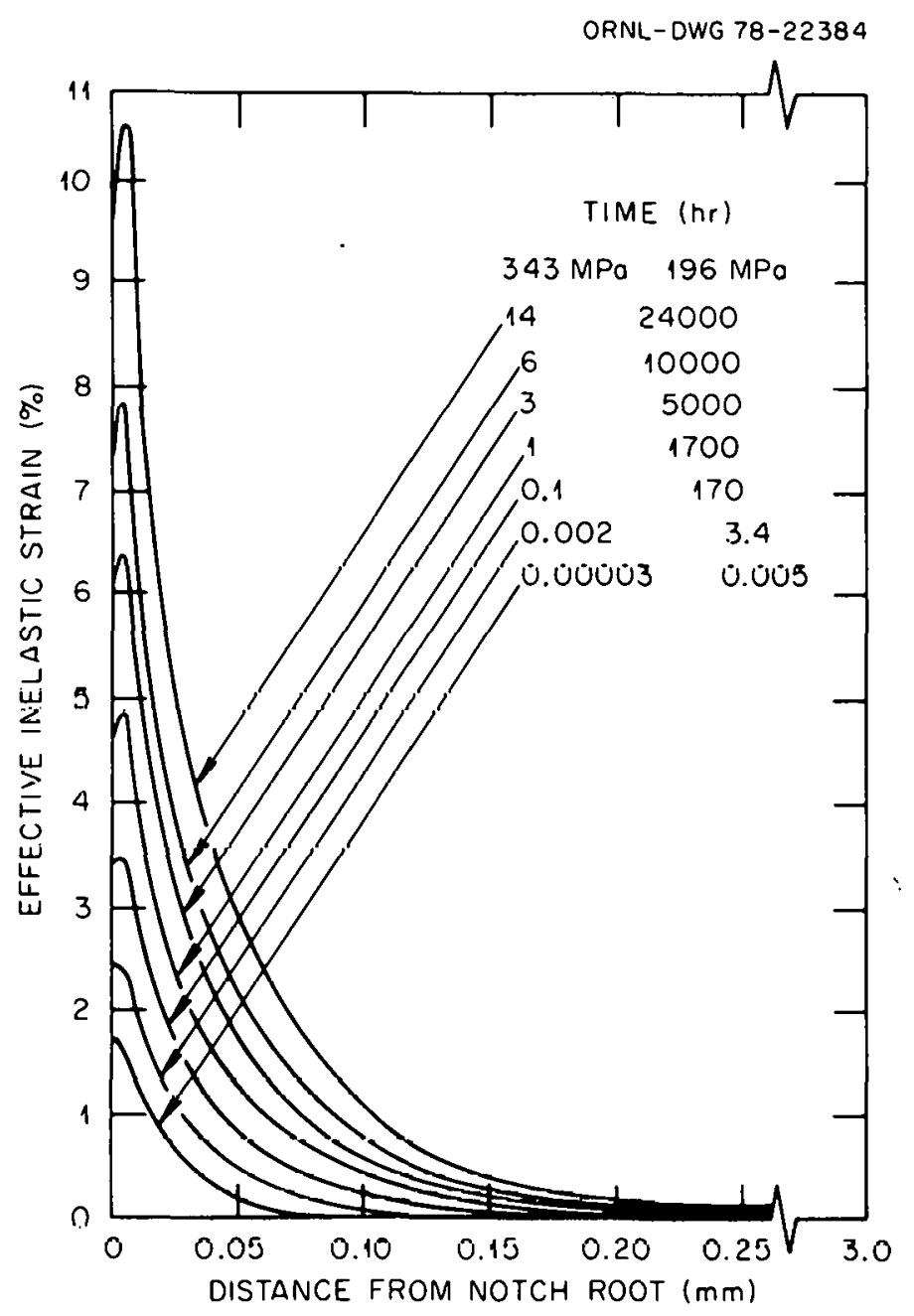

Fig. 6. Effective strain vs distance from notch root at minimum cross section. ( $1 \mathrm{~mm}=0.0394$ in.) (From Taira and Ohtani, "Creep Crack Propagation and Creep Rupture of Notched Specimens," Creep and Fatigue in Elevated Temperature Applications, Institution of Mechanical Engineers, 1974.)

plasticity effects was taken, although the calculated stress levels make it clear that those must be significant. Add1tionally, the analysis showed strains of around $10 \%$, making the use of the linearized straindisplacement relations questionable. Finally, it is not apparent how the location of the maxima of the effective creep strain and the effective stress could differ from each other, particularly in view of the fact that the authors employed a steady-state creep law that ignores the primary creep phase. 
A more detailed (but less ambitious) finite-element analysis was performed by Lawton, ${ }^{14}$ who considered the case of a parallel-sided notch $(\phi=0)$ with $\mathrm{d} / \mathrm{D}=0.851$ and $\mathrm{r} / \mathrm{d}=0.0282$. A strain-hardening creep law was employed and the effects of plasticity were taken into account. The material constants used were appropriate to the ferritic steel $1 \mathrm{Cr}-1 / 2$ Mo at $593^{\circ} \mathrm{C}\left(1100^{\circ} \mathrm{F}\right)$.

Lawton's analysis considered both the case of constant-load creep and constant-displacement stress relaxation. Figures 7 and 8 , respectively, show the calculated axial stress and strain distributions across

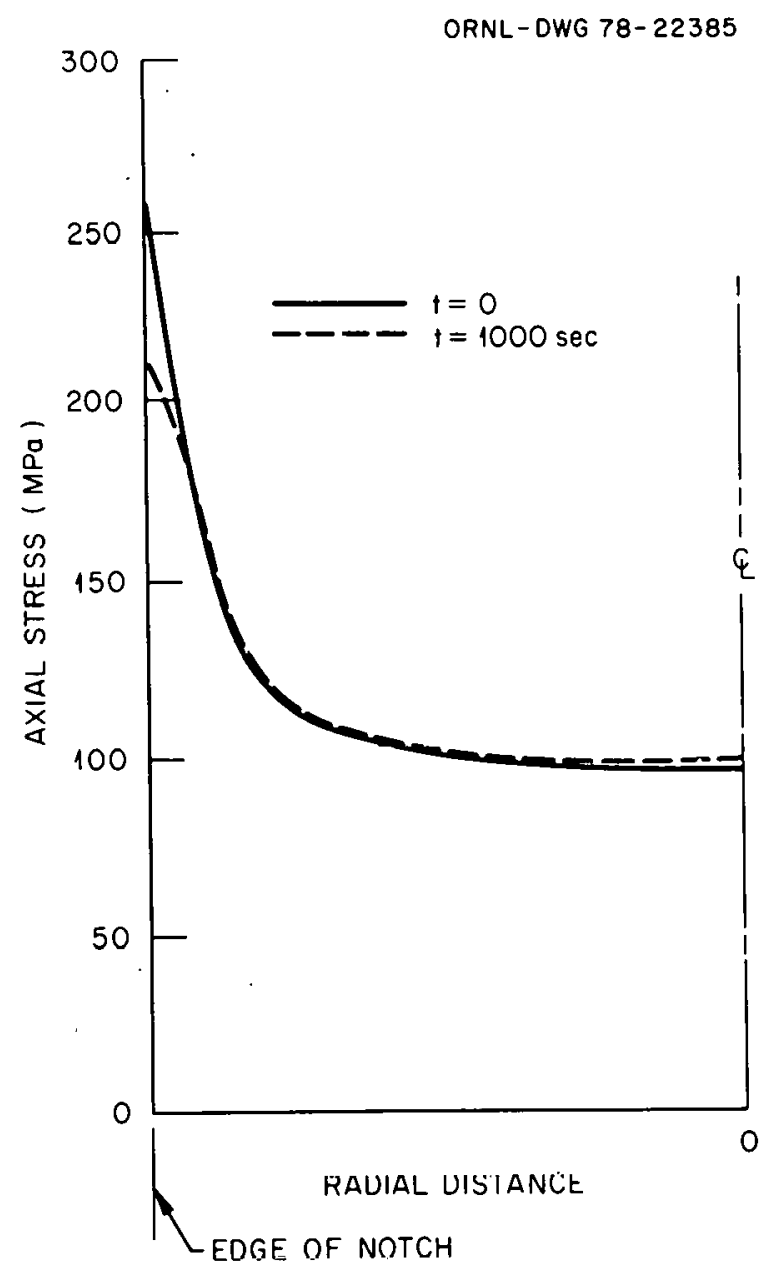

Fig. 7. Calculated axial stress distribution across minimum cross section. ( $\mathrm{MPa}=0.145 \mathrm{ksi}$ ) (From C. W. Lawton, "Strain Concentration in a Notched Round Bar Subject to Creep," Second International Conference on Pressure Vessel Technology, ASME, 1973.) 


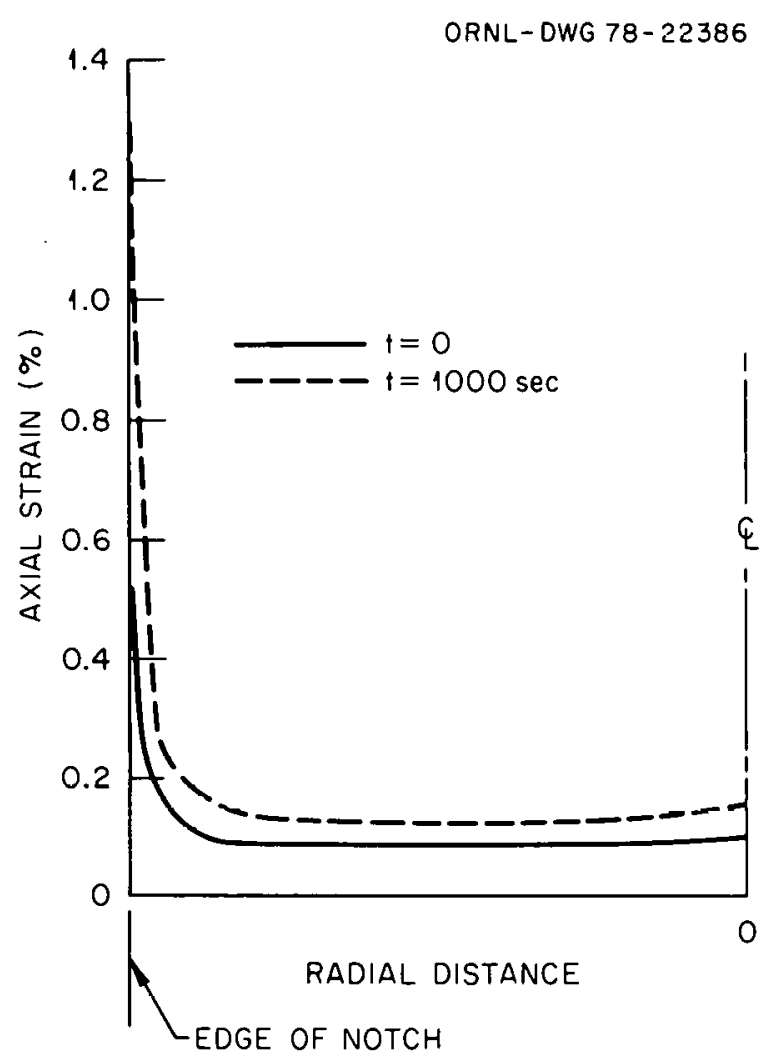

Fig. 8. Calculated axial strain distribution across minimum cross section. (From C. W. Lawton, "Strain Concentration in a Notched Round Bar Subject to Creep," Second International Confexence orl Pressure Vessel Tecilluivui4, ASRE, 1973.)

the minimum cross section for constant-load creep. In contrast to l'aira and Ohtani's results, the maximum value of the axial stress is always located at the notch root. A reduction of $225 \%$ in axial stress at the notch root is observed after $1000 \mathrm{sec}$ of creep, but the value in the central portion of the specimen remains relatively constant.

Consider briefly the results of those analyses in light of several proposed creep-rupture criteria. The most widely used of such criteria is the time-fraction approach advocated by the American Society of Mechanical Engineers (ASME) Code, ${ }^{15}$ which is based on effective stress. An alternate criterion, proposed by Manjoine ${ }^{i 6}$ for application to ductile materials, makes use of effective creep strain as a measure of damage. Unfortunately, Lawton presents no results for effective stress or creep strain, so we must rely on the possibly flawed analysis of Taira and 
Ohtani for information about the behavior of those quantities. Considering first the effective stress, note from Fig. 4 that Taira and Ohtani's analysis indicates that the ratio of effective stress to nominal stress at the minimum cross section relaxes to a value below unity for significantly long times. Similarly, by using the steady-state creep rates found by Taira and Ohtani in their smooth-bar specimens, it may be determined that the maximum effective creep strain values shown in Fig. 6 are less than the corresponding smooth-bar values for significantly long times.

The maximum effective stress and creep strain in a notched specimen may be in excess of the corresponding smooth-bar values at shorter times but less than these values at longer times; this fact offers a possible explanation for the notch-strengthening or notch-weakening phenomenon in terms of the time-fraction approach taken by the ASME Code or the strain limit damage criterion proposed by Manjoine. Thus, presumably in the case of notch strengthening, the maximum equivalent stress or strain would be less than the smooth-bar values for a sufficient period of time so that the damage fraction, whether computed by means of strain limits or time fractions, would still be less than unity at the time of smoothbar failure. The converse situation would presumably occur in the case of notch weakening.

To consider notched-specimen creep-rupture behavior in slightly greater detail, several investigators ${ }^{7,8}$ have indicated that experimental evidence often seems to point to a location just intertor to the notch root as the side where microcracking first begins. Taira and Ohtani's analysis shows a maximum in the effective creep strain at a point to the interior of the notch root (Fig. 6). This result, if correct, might tend to support a creep damage criterion based on effective creep strain rather than effective stress for the $1 \mathrm{Cr}-1$ Mo-1/4 $\mathrm{V}$ steel considered by Taira and Ohtani. Such a criterion, in fact, was used by these authors in making specimen failure predictions.

In light of the possible errors in Taixa and Ohtani's analysis, it is not possible to have a great deal of confidence in their numerical results. These results do, however, raise some interesting points that 
a more comprehensive finite-element analysis might help to clarify. Such an analysis is now under way at Oak Ridge National Laboratory (ORNL).

\section{NOTCH EFFECTS IN WELDMENTS}

Experience with pressure vessel and piping structures has shown that a significant percentage of the failures in these structures occur in the neighborhood of weldments. Thus, because flaws can frequently exist in weldments, we are interested in investigating the effect. of flaws in weldments by means of notched-specimen tests.

Williams and Willoughby ${ }^{17}$ performed a series of axisymmetric notchedbar tests of weldments in type 316 stainless steel, as well as weldments in austenitic steels identified as Esshete 1250, G19, and G68. The weld metal used in the 316 stainless steel specimens was identified as Armex GT. The specimens were designed so that half the specimen contained essentially weld metal and the other half base metal, and that the notch was located near the weld fusion line in the heat-affected zone (HAZ). The tests were carried out at $600^{\circ} \mathrm{C}\left(1110^{\circ} \mathrm{F}\right)$. Figure 9 shows the failure behavior of the notched 316 stainless steel weldment specimens for three different postweld heat treatments: (1) none, (2) $3 \mathrm{hr}$ at $850^{\circ} \mathrm{C}\left(1560^{\circ} \mathrm{F}\right)$, and (3) $1 \mathrm{hr}$ at $1050^{\circ} \mathrm{C}\left(1920^{\circ} \mathrm{F}\right)$. Data for several notched a1.1-base-metal specimens that were heat-treated to simulate HAZ material are included for comparison. The weldment specimens that have had a $1-\mathrm{hr}, 1050^{\circ} \mathrm{C}\left(1920^{\circ} \mathrm{F}\right)$ postweld heat treatment do not behave very differently from the all-basemetal, simulated $\mathrm{HAZ}$ material. The as-deposited specimens and those with a $3-\mathrm{hr}, 850^{\circ} \mathrm{C}\left(1560^{\circ} \mathrm{F}\right)$ postweld heat treatment also behave similarly but exhibit a sharp drop in stress for failure times in excess of about 300 hr. All the curves in Fig. 9 were found to fall above that for an unnotched specimen of all-base-metal, simulated HAZ material. Thus, at least for the notch geometry considered, the type 316 stainless steel simulated HAZ specimens and weldment specimens were found to be notch strengthened.

A limited number of similar tests have been carried out by Manjoine ${ }^{18}$ on as-deposited 304 stainless steel base-metal/308 stainless steel weldmetal specimens at $593^{\circ} \mathrm{C}\left(1100^{\circ} \mathrm{F}\right)$. Two specimens in which the notch was 
ORNL-DWG 78-22387

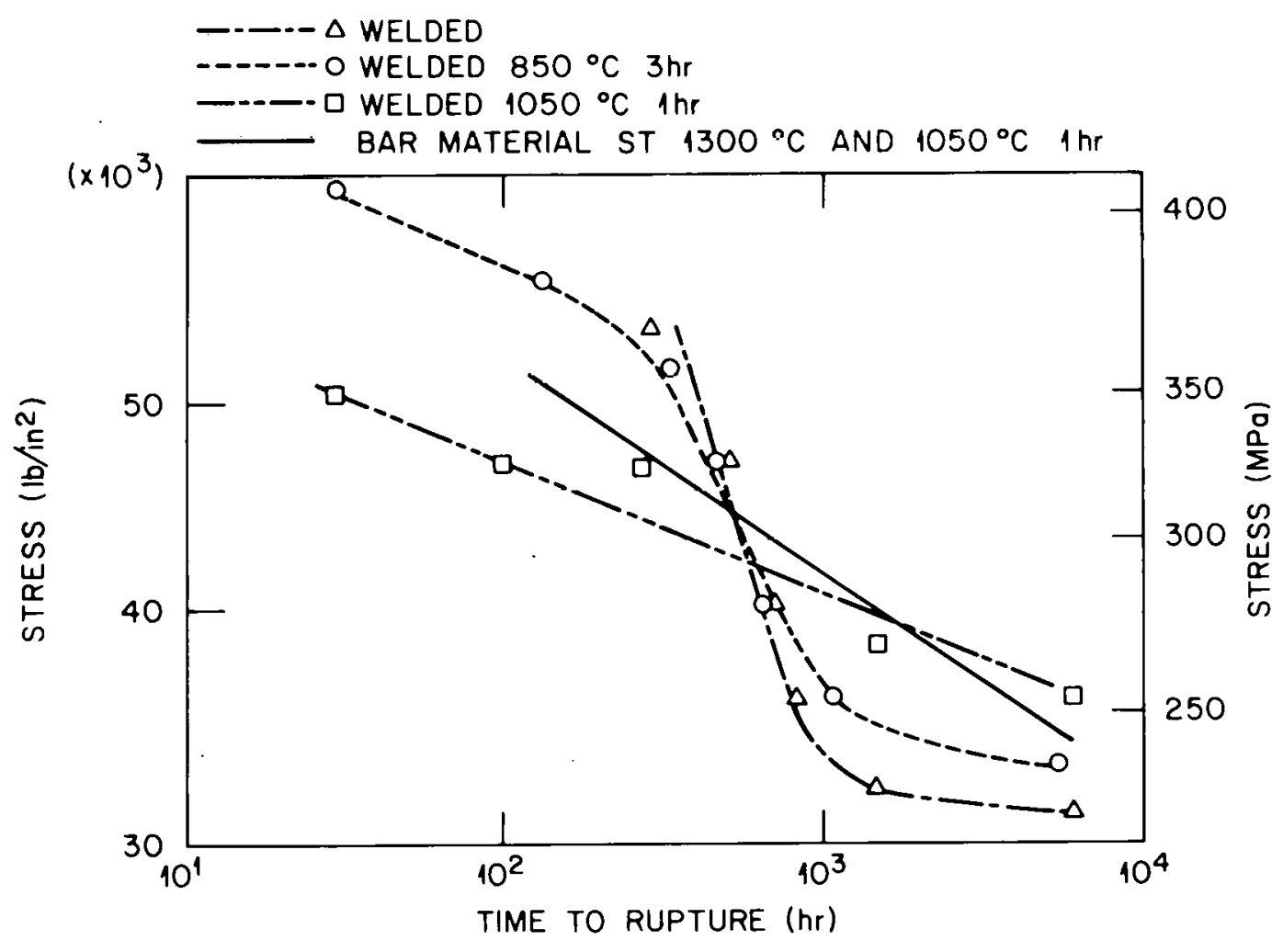

Fig. 9. Failure behavior of notched weldment specimens of 316 stainless steel. ( $1 \mathrm{MPa}=0.145 \mathrm{ksi}$.) (From Williams and Willoughby, "The Notch Rupture Behavior of some Austenitic Steels," Joint International Conference on Creep, Institution of Mechanical Engineers, 1963.)

located in the HAZ failed at about the same nominal stress as an unnotched a1.1-base-metal specimen, indicating no marked notch-strengthening or notch-weakening effect. Three other specimens in which the notch was located in the weld metal seem to exhibit a mild notch-strengthening effect with respect to unnotched all-weld metal specimens.

\section{CONCLUSIONS}

A review of the available literature in the area of notch effects at high temperatures has indicated that notch strengthening or weakening is not to be thought of as a property intrinsic to a given material but instead is a complex phenomenon dependent on stress level, temperature, notch geometry, specimen size, specimen heat treatment, etc. To date, 
most of the explanations of this phenomenon have been of a qualitative nature, and little quantitative analysis of the problem has been done. However, the notch-strengthening phenomenon is clearly related to the relaxation of the high stresses present near the root of the notch. A detailed finite-element analysis using realistic material properties could do much to provide a more quantitative understanding of notchedspecimen behavior.

Literature reports on the effect of notches in weldments are not numerous. Two papers in this area were reviewed - one reporting the effects of notches in type 316 stainless steel wcldments, and the other in type 304 stainless steel base-metal/type 308 weld-metal weldments. For the range of notch gcomctries, specimen loads, and test temperatures considered in these papers, the notches were found to have either no effect or a mild strengthening effect on the failure times.

\section{REFERENCES}

1. Amer. Soc. Test. Mater., Book of ASTM Stand., Part IV, Section E-292, American Society for Testing Materials.

2. Symposium on Strength and Ductility of Metals at Elevated Temperatures, STP No. 128, American Society for l'esting Materials, 1952.

3. W. F. Brown, Jr., et al., Lilerature Surveys on Irlftuence of Stress Concentrations at Elevated Temperatures and the Effects of Non-Steady Load and Tomporaturo Conditiono on the Crocp of Mctalo, ETP No. 260, American Society for Testing Materials, 1959.

4. J. Basic Eng. 84(2) (June 1962).

5. J. D. Lubahn and G. V. Smith, "Introductory Summary," Symposium on Strength and Ductility of Metals at Elevated I'emperatures, STP No. 128, American Society for Testing Materials, 1952.

6. W. F. Brown, Jr., "Summary of the Session," J. Basic Eng. 84(2), 243-46. (June 1962).

7. E. A. Davls and M. J. Manjo1ne, "Effect of Notch Ceometry on Rupture Strength at Elevated Temperatures," Symposium on Strength and Ductility of Metals at Elevated Temperatures, STP No. 128, American Society for Testing Materials, 1952.

8. H. R. Voorhees, J. W. Freeman, and J. A. Herzog, "Trends and Implications of Data on Notched-Bar Creep Rupture," J. Basic Eng. 84(2), 202-13 (June 1962).

9. M. J. Manjoine, "Size Effect on Notched Rupture Time," J. Basic Eng. $84(2), 220-21$ (June 1962). 
10. W. H. Couts, Jr., and J. W. Freeman, "Notch Rupture Behavior as Influenced by Specimen Size and Preparation," J. Basic Eng. 84(2), 222-27 (June 1962).

11. A. K. Schmieder, "Size Effect in Creep and Rupture Tests on Unnotched and Notched Specimens of $\mathrm{Cr}-\mathrm{Mo}-\mathrm{V}$ Steel, Current Work on Behavior of Materials at Elevated Temperatures, ed. by A. 0. Schaefer, American Society of Mechanical Engineers, New York, 1974.

12. M. J. Manjoine, "Discussion of Paper C213/73," Creep and Fatigue in Elevated Temperature Applications, Vol. 2, p. 39, Institution of Mechanical Engineers, London (1974).

13. S. Taira and R. Ohtani, "Creep Crack Propagation and Creep Rupture of Notched Specimens," Creep and Fatigue in Elevated Temperature Applications, Vo1. 1, Paper C213/73, Institution of Mechanical Engineers, London (1974).

14. C. W. Lawton, "Strain Concentration in a Notched Round Bar Subject to Creep," Second Intermational Conference on Pressure Vessel Technology, American Society of Mechanical Engineers, 1973.

15. Code Case N-47-13, Cases of the ASME Boiler and Pressure Vessel Code, American Society of Mechanical Engineers, New York, 1974.

16. M. J. Manjoine, "Elevated Temperature Mechanics of Metals," Proceedings of the 1974 Symposium on the Mechanical Behavior of Materials, Kyoto, Japan (1974).

17. N. T. Williams and G. Willoughby, "The Notch Rupture Behavior of Some Austenitic Steels," Toint International Conference on Creep, Institution of Mechanical Engineers, London (1963).

18. "W-ARD Submittal of Mechanical Properties, Contribution for the Period Ending December 31, 1977," WARD-3045-80160, Advanced Reactors Division, Westinghouse Electr1c Corporation, Madison, $\mathrm{Pa}$. 
ACKNOWLEDÉMENTS

The author is grateful to W. K. Sartory and R. W. Swindeman for their helpful comments. He also wishes to acknowledge the assistance of $\mathrm{D}$. T. Godwin in the preparation of the figures. 
ORNL/TM-6716

Dist. Category UC-79, $-79 \mathrm{~h},-79 \mathrm{k}$

\section{Interna1 Distribution}

1. R. L. Battiste

2. J. J. Blass

3. C. R. Brinkman

4. J. W. Bryson

5. J. A. Clinard

6. W. E. Cooper

7-21. J. M. Corum

22-24. T. J. Delph

25. W. G. Dodge

26. J. R. E1lis

27. W. L. Greenstreet

28. R. C. Gwaltney

29. J. F. Harvey

30. R. L. Huddleston

31. R. T. King

32. R. L. Klueh

33. Milton Levenson

34. K. C. Liu

35. W. J. McAfee

36. H. E. McCoy
37. J. G. Merkle

38. S. E. Moore

39. P. Patriarca

40. C. E. Pugh

41. M. Richardson

42. D. N. Kobinson

43. G. C. Robinson

44. W. K. Sartory

45. V. K. Sikka

46. G. M. Slaughter

47. J. E. Smith

48. R. W. Swindeman

49. H. E. Trammel1

50. G. D. Whitman

51. G. T. Yahr

52. Patent office

53-54. Central Research Library

55. Y-12 Document Reference Section

56-61. Laboratory Records Department

62. Laboratory Records (RC)

\section{Externa1 Distribution}

63-64. Director, Division of Reactor Research and Technology, Department of Energy, Washington, DC 20545

65. Associate Director, Nuclear and Engineering Technologies, ORO

66. Program Director, Nuclear Reactor Technology Programs, ORO

67. Assistant Manager, Energy Research and Development, DOE-ORO

68-322. Given distribution as shown in TID-4500 under categories UC-79, $-79 h,-79 k$ 